\title{
"If I won the lottery...": work orientations of low-qualified young adults in Albania and Switzerland
}

\author{
Nada Kallciu ${ }^{1} \cdot$ Eralda Zhilla $^{1} \cdot$ Laurence Fedrigo $^{2} \mathbb{D} \cdot$ Livia Nano $^{1} \cdot$ \\ Jonas Masdonati ${ }^{2,3}$
}

Received: 5 October 2020 / Accepted: 20 May 2021 / Published online: 2 June 2021

(c) The Author(s) 2021

\begin{abstract}
A qualitative study was carried out to portray the work orientations of 30 low-qualified working young adults in two contrasted economies: Albania and Switzerland. The analysis of their answers to the "lottery question" showed that most participants would continue to work, either to be busy, feed a passion, feel useful, or grow. In contrast to participants from Switzerland, Albanian participants would more easily modify some aspects of their work. Globally, findings reveal that participants' current situations tend to differ from what they expect from work, which impacts the quality of their work integration and has critical implications for career counseling.
\end{abstract}

Keywords Lottery question · Work orientation $\cdot$ Low-qualified youth

\section{Résumé}

"Si je gagnais à la loterie..." : Orientations envers le travail de jeunes adultes peu qualifiés·es d'Albanie et de Suisse

Une recherche qualitative a été réalisée afin de décrire les orientations envers le travail de 30 jeunes adultes peu qualifiés-es travaillant dans deux économies contrastées: l'Albanie et la Suisse. L'analyse des réponses à la "question de la loterie" a montré que la plupart des participants·es continueraient à travailler pour être occupés·es, nourrir une passion, se sentir utiles ou se développer. Comparativement aux jeunes suisses, les participants-es albanais-es modifieraient davantage certains aspects de leur travail. Globalement, les résultats révèlent que la situation actuelle des participants·es a

Nada Kallciu

nkallciu@gmail.com

Laurence Fedrigo

laurence.fedrigo@unil.ch

1 Department of Pedagogy and Psychology, University of Tirana, Tirana, Albania

2 Institute of Psychology, University of Lausanne, Lausanne, Switzerland

3 Swiss National Centre of Competence in Research LIVES - Overcoming Vulnerability: Life Course Perspectives (NCCR LIVES), University of Lausanne, Lausanne, Switzerland 
tendance à différer de leurs attentes envers le travail, ce qui affecte la qualité de leur insertion professionnelle et comporte des implications cruciales pour l'orientation professionnelle.

\section{Zusammenfassung}

"Wenn ich im Lotto gewinne...": Arbeitsorientierungen geringqualifizierter junger Erwachsener in Albanien und der Schweiz

In einer qualitativen Studie wurden die Arbeitsorientierungen von 30 gering qualifiziert arbeitenden jungen Erwachsenen in zwei kontrastierenden Volkswirtschaften dargestellt: Albanien und der Schweiz. Die Analyse ihrer Antworten auf die "Lotterie-Frage" zeigte, dass die meisten Teilnehmer weiterhin arbeiten würden, entweder um beschäftigt zu sein, eine Leidenschaft zu nähren, sich nützlich zu fühlen oder um zu wachsen. Im Gegensatz zu den Teilnehmern aus der Schweiz würden die albanischen Teilnehmer eher einige Aspekte ihrer Arbeit ändern. Insgesamt zeigen die Ergebnisse, dass die aktuelle Situation der Teilnehmer tendenziell von dem abweicht, was sie von der Arbeit erwarten, was sich auf die Qualität ihrer Arbeitsintegration auswirkt und kritische Implikationen für die Karriereberatung hat.

\section{Resumen}

"Si me toca la lotería..." Orientación para el trabajo de jóvenes adultos poco cualificados en Albania y Suiza

Se desarrolló un estudio cualitativo para describir la orientación al trabajo de 30 trabajadores jóvenes adultos en dos economías de contraste: Albania y Suiza. El análisis de sus respuestas a la "pregunta de la lotería" mostró que la mayoría de los participantes habrían continuado trabajando, tanto para sentirse ocupados, alimentar su pasión, sentirse útiles o crecer. En contraste a los participantes de Suiza, los de Albania habrían modificado más fácilmente algunos aspectos de su trabajo. Globalmente, los resultados revelan que la situación actual de los participantes tiende a diferir respecto de lo que esperaban del trabajo, lo que tiene un impacto sobre la calidad de su integración en el trabajo y tiene implicaciones críticas para la orientación profesional.

\section{Introduction}

The contemporary world of work is characterized by increasing volatility, flexible careers and a growing number of career transitions (Fouad \& Bynner, 2008; Tomlinson et al., 2018). In this context, many workers have to cope with job insecurity and precarious work (Blustein et al., 2017, 2019; Schoon \& Heckhausen, 2019). Given these changes, understanding the meaning individuals attach to their work becomes salient (Fournier et al., 2020). Specifically, it is crucial to grasp if and how doing insecure and precarious jobs affects the meaning that people attach to work in their lives, as well as to take into account contextual factors-such as labor market conditions-when studying this issue (Cohen-Scali et al., 2020; Kazimna et al., 2020). Moreover, given that integrating the labor market often leads to job insecurity (Kenny et al., 2019; Organisation for Economic Co-operation and Development 
[OECD], 2017b) and that the transition from education to work has long-term impacts on careers (Krahn et al., 2015; Yeung, \& Yang, 2020), understanding young adults' meaning of work has become an important research topic (Masdonati, \& Fournier, 2015). The present study focused on the meaning of work of low-qualified young adults experiencing job insecurity within two contrasted socioeconomic contexts: Albania and Switzerland. Meaning of work were addressed through the lens of the notion of work orientation, defined as the purpose people pursue through work in order to bring meaning to their life (Willner et al., 2020). In turn, work orientations were assessed through the so-called "Lottery question" (Highhouse et al., 2010).

\section{Transitions to work}

The school-to-work transition (STWT) is a significant moment of people's career paths (Masdonati et al., 2021; Vuolo et al., 2014), given that the first occupational experiences influence careers in the long-term (Egdell \& Beck, 2020; Yeung, \& Yang, 2020). For example, early employment instability negatively impacts later earnings, occupational status, and career satisfaction (Krahn et al. 2015). Educational factors and labor market conditions are among the most important determinants of the quality of the STWT process (Masdonati et al., 2021). In general, young people with higher levels of education have better chances to find a job and access secure careers (Danziger \& Ratner, 2010). In contrast, low- or underqualified young adults - i.e., people with high school degree or less - are at higher risk of floundering transitions and long-term job insecurity (Vuolo et al., 2014).

Tight labor market conditions also negatively influence the quality of the STWT, and exacerbate the impact of education and qualifications on this process (Danziger \& Ratner, 2010; Schoon \& Lyons-Amos, 2016). Economic downturns have indeed a strong impact on youth, who are particularly exposed to unemployment compared to adult workers (Yeung, \& Yang, 2020). For example, during the 2008 recession, lowqualified youth were more strongly hit, and experienced higher levels of underemployment and unemployment than more educated youth (Schoon \& Bynner, 2019). Moreover, the economic globalization has resulted in an increase of young adults' job insecurity, characterized by flexibility, short-term or no contract, low pay, and bad working conditions. Thus, low-qualified young workers are particularly exposed to unemployment, but also to underemployment, job insecurity, and precariousness (Yeung \& Yang, 2020). It becomes then important to understand if and how these STWT difficulties affect their work expectations. This can be done through the lens of the meaning of work and work orientation concepts.

\section{Meaning of work and work orientations}

Understanding what makes work meaningful-i.e., the meaning of work-is a significant issue within contemporary careers (Fournier et al., 2020). More specifically, the meaning young people attach to work might be considered as a psychosocial underpinning of the STWT (Masdonati \& Fournier, 2015). The literature on this topic suggests a differentiation between the notions of meaning in work and 
meaning of work. Meaning in work refers to the amount of meaning people can find in their work, whereas meaning of work refers to the type of meaning people attach to this life sphere (Rosso et al., 2010). Authors agree on the multidimensionality of the concept of the meaning of work. The meaning people attach to work depends indeed, among others, on the absolute and relative centrality of work in their life, the values or goals they wish to achieve though work, how they perceive their duties and obligations within the working sphere, and the purposes they ascribe to work in their life (Fournier et al., 2020; Harpaz \& Fu, 2002).

The concept of meaning of work encompasses the notions of work commitment (Wielers \& van der Meer, 2020) and orientation (Willner et al., 2020). Wielers and van der Meer (2020) refer to the notion of work commitment as a mean to measure intrinsic work motivation, which depends on "the extent to which paid work satisfies the human needs of autonomy, competence, and relatedness" (p. 1). The authors found that opportunities for development, social contacts, autonomy and job security increased work commitment. They also highlighted that low-paid workers and those in less good health tend to have lower work commitment. In a similar way, work orientations refer to the fundamental goals that people expect to achieve through their work (Willner et al., 2020). Initial conceptualizations of the construct stressed the existence of three orientations, depending on whether work is considered as a job, a career, or a calling (Wrzesniewski et al., 1997). When people expect from work compensation and material rewards, they are considered as job-oriented; workers are career-oriented when they aspire to improve their status and to advance; a calling orientation to work refers to people who see work as a mean to make a difference in the world. Recently, Willner et al. (2020) and Lipshits-Braziler et al. (2020) revealed the existence of two additional types of work orientations: busyness and social embeddedness. According to Willner et al. (2020), "Busyness-oriented individuals work primarily as a way to occupy their time", whereas "social embeddedness-oriented individuals work mainly as a way of being part of a group or an organization" (p. 111). The lottery question represents an effective mean to highlight individuals' work orientations and ultimately understand their work commitment.

\section{The lottery question}

The "lottery question" consists of asking people whether they would continue doing their paid job after having won in a lottery. It is used in the literature to measure the extent to which work has a function that is other than instrumental (Highhouse et al., 2010; Sharabi \& Harpaz, 2019; Wielers \& van der Meer, 2020; Willner et al., 2020). Asking people if they would continue working even if they had enough money to live a decent life indeed indicates if they are other than job-oriented. With the recent shift of emphasis from industry and achievement to personal growth (Highhouse et al., 2010), the lottery question allows the researchers to bring forth the underlying reasons individuals have for continuing to work, even without financial needs. Based on quantitative surveys, existing studies show variations in the rate of people answering positively to the lottery question. For example, the higher the education level, job satisfaction and work importance, the higher the likelihood to continue working despite winning the lottery (Arvey et al., 2004; Sharabi \& Harpaz, 2019). 
Demographic characteristics and the historical and cultural context also seem to affect the proportion of people that would continue working even if they won the lottery (Highhouse et al. 2010; Sharabi \& Harpaz, 2019). For example, young workers tend to answer more positively to the lottery question than adult workers (Highhouse et al., 2010), work engagement is higher in society with strong survival values compared to ones based on self-expression values (Snir \& Harpaz, 2009), and individuals are expected to engage more in unpaid activities when the economy is prosperous (Highhouse et al., 2010).

\section{Study contexts}

Albania is a 2.8-million habitants country, with a large amount of Albanian people leaving the country for economic or educational reasons (Kamberi \& Çela, 2019). The Albanian labor market is mainly concentrated in the agricultural sector, followed by the service sector (Cernaj, 2019). The unemployment rate of young adults (15-29 years old) was estimated at 22\% in 2015, whereas $14 \%$ of the youth workforce was working in jobs that were not productive and rewarding enough (de Bruijn et al., 2015). Moreover, $63 \%$ of the unemployed youth are unemployed for a long time, and the ratio of youth not in employment, education or training (NEET) was $29.7 \%$ in 2017 (Cernaj, 2019). A weak link between education and the labor market can explain the difficulties of young people to find a job after graduation, unemployment being higher among people with higher education than among youth with compulsory education (Cernaj, 2019; Hoxhaj, 2017). A high rate of young people having completed vocational education, or even a bachelor or master's degree in Albania are facing unemployment, or are being presented with job offers that do not provide them with the necessary means to cover their live expenses. Because of these conditions, they are often obliged to accept positions that are below their level of education, like jobs in bars, restaurants, or call centers, while hoping to find a better position in the future. For this reason, many young adults leave Albania to find a job in countries that have higher economical standards and lower unemployment rates. In other cases, they return to their cities or villages of origin and live with their parents to be able to cover their financial needs.

Switzerland is an 8.5-million habitant country, one out of four habitants being of foreign origin (Federal Statistical Office, 2018). Its labor market is largely composed of small- and medium-size organizations and high-qualified workers, mainly employed in the service sector (Nathani et al., 2017). Compared with the OECD countries, the Swiss labor market is considered as highly performing according to many indicators, such as unemployment rates and earnings (OECD, 2017a). More than nine out of 10 workers have a post-compulsory diploma (i.e., a vocational education, college, or university degree; Federal Statistical Office, 2018), and only $2.5 \%$ of the active population suffers from precariousness, namely underemployment, income insecurity, or fixed-term contracts (Mattmann et al., 2017). NEET and youth unemployment rates in Switzerland are among the lowest within European countries, which is explained, among other things, by a performing vocational education and training system (State Secretariat for 
Economic Affairs, 2017). The unemployment rate of $15-24$ old was $6.2 \%$ in 2019 , and the ratio of NEETs was $6 \%$ in 2018, whereas it was, respectively, $14 \%$ and $10.5 \%$ within the EU-28 (Federal Statistical Office, 2019). However, lowqualified young people have significantly higher risks of job precariousness and long-term unemployment than the adult population (Egger et al., 2020; Meyer, 2018).

In sum, Albania and Switzerland can be considered as two contrasted, small European countries according to labor market indicators and degree of individualism. Particularly, Albania has significantly higher rates of NEET and unemployed young people than Switzerland, whose education system seems to better facilitate the transition from school-to-work. Moreover, labor market integration chances are better for high-qualified youth in Switzerland, whereas this is not the case in Albania. These differences might explain why many Albanian people leave the country to find better work opportunities in other European states, whereas Switzerland is an attractive country for the foreign workforce. Beyond these oppositions, in both countries young people experience a higher risk of unemployment and precarious jobs when compared with adult workers.

\section{Study aims}

Extant "lottery studies" exclusively focus on the ratio of positive and negative answers to the lottery question, and little is known concerning the determinants of the answers (Wielers \& van der Meer, 2020). In our research, we posit that, if addressed through a qualitative design, the lottery question is a powerful input not only to address the ratio of busyness-oriented people within a given population, but also to inductively identify the whole range of people's work orientations and to compare answers between contexts. Indeed, asking people to explain what they mean when answering "yes" or "no" to this question opens up to explanations on what kind of meaning they attach to work. The first aim of our study was then to portray the work orientations of low-qualified young adults in precarious jobs through their explanations of the answers given to the lottery question.

Moreover, given the influence of the cultural and socioeconomic context on the meaning of work and, specifically, on the answers to the lottery question (Highhouse et al., 2010; Sharabi \& Harpaz, 2019), our second study aim was to compare the work orientations of precarious young adults in two contrasted European contexts, namely Albania and Switzerland. First, these two contexts are indeed different from a cultural viewpoint; their comparison based on Hofstede's criteria (hofstede-insights.com) shows that Albania rates 20 in the Individualism dimension against 68 for Switzerland. Albania is then a more collectivist society, fostering strong relationships between people, where individuals have responsibilities towards their family. In contrast, Switzerland is a more individualist society, where people are expected to be responsible for themselves. Second, Albania and Switzerland have also contrasted socioeconomic contexts, specifically regarding the STWT and labor market integration. 


\section{Methods}

Based on a qualitative approach, we used semi-structured interviews to access low-qualified young workers' subjective experience and perception of work and describe what they have in common, with the purpose of reaching the essence of this phenomenon.

\section{Participants and procedure}

The sample was composed of 30 low-qualified young workers, 15 from Albania and 15 from Switzerland. Participants were 14 women and 16 men aged from 20 to 26 years old $(M=22,6 ; S D=1,9)$, having a job that required no qualification, mainly in the fields of handling, social work, service, sales, and security (Table 1). They all came from low to average socio-economic milieus based on their parents' employment status, occupation, and income level. Among the Albanian participants, seven were living in the capital city and eight in smaller cities or the countryside; 13 participants completed compulsory education, and all were of Albanian nationality. The participants within the Swiss sample were living in two French-speaking cities. Among them, eight participants had the Swiss nationality, half of which were binational, and seven were of foreign origin (Cameroon, Italy, Portugal, and Spain). With the exception of two participants, the majority had completed compulsory education either in Switzerland or abroad for four participants. Four participants had also completed a low-level VET program in Switzerland.

Recruitment was made on a voluntary basis and purposive sampling was used to select participants based on three inclusion criteria: being between 18 and the late $20 \mathrm{~s}$; having a job requiring no qualifications as the main source of income; and having an education level equal or lower than compulsory education or low-level VET. Face-to-face semi-structured interviews lasted from $45 \mathrm{~min}$ to one hour and $45 \mathrm{~min}$ and were carried out by the first and second authors in Albania, and by two master students in Switzerland. Interviews were fully recorded and transcribed with the participants' consent, and pseudonyms were used to protect their identity.

\section{Interview guideline}

The study was part of an international research project on work representations of low-qualified young workers in diverse countries, carried out within Name of the network (reference). The interview guideline was consensually constructed by the scholars affiliated to the international project. The interviews were divided in four parts, covering four main themes. The first part explored participants' work representations with questions such as "According to you, what are the characteristics of a 'good' job?" The second part addressed their current work situation; participants were asked, for instance, to describe to what extent they were satisfied with their working hours, environment and conditions. The third part investigated their life path by asking, for example, "Can you describe your school and professional path?" The fourth 


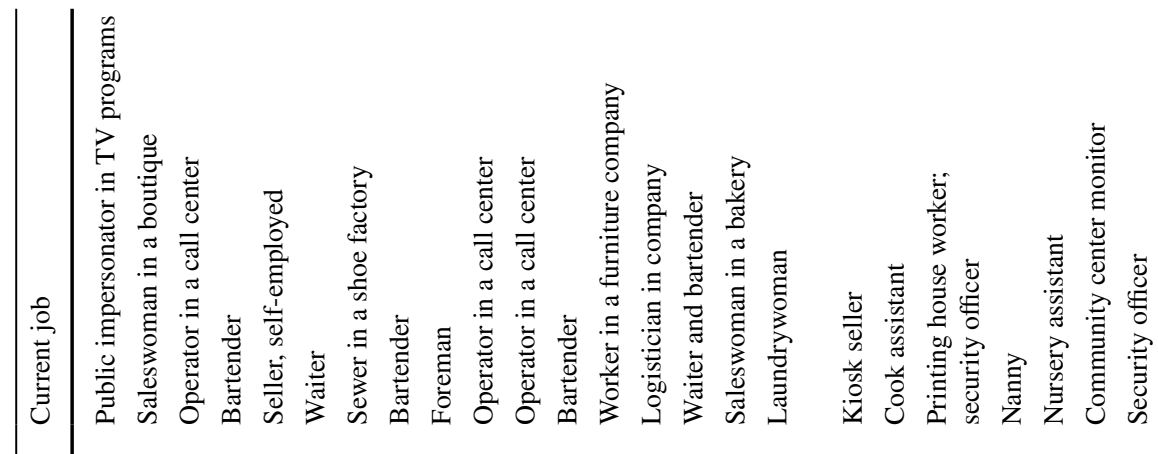

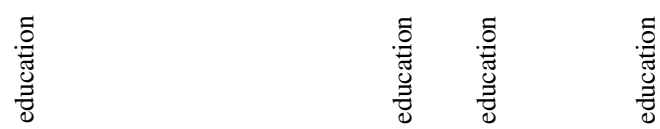

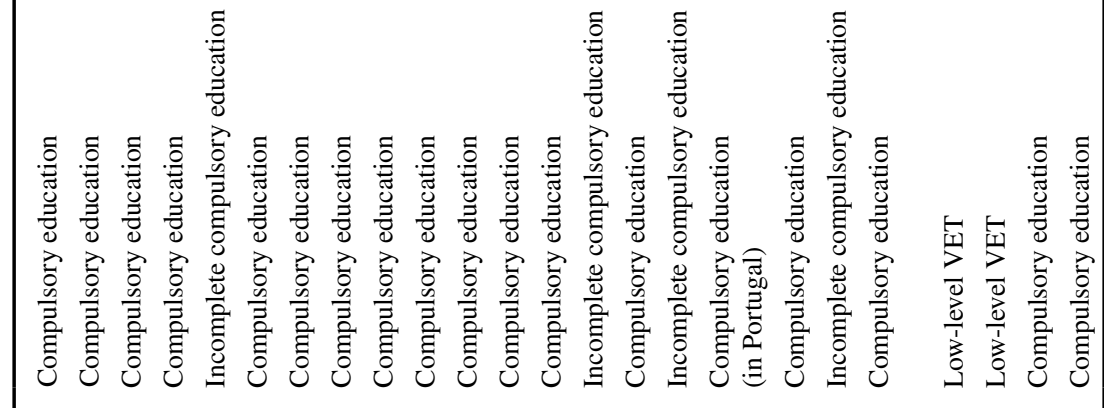

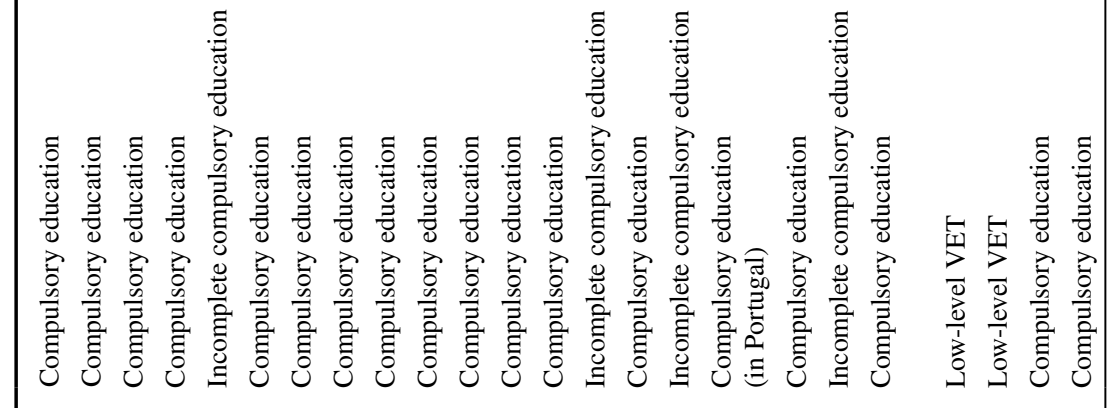

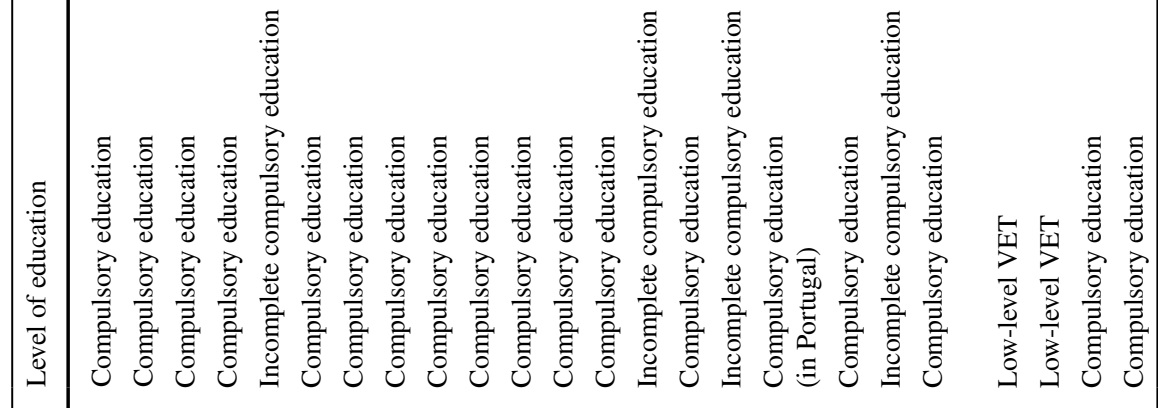

एँ

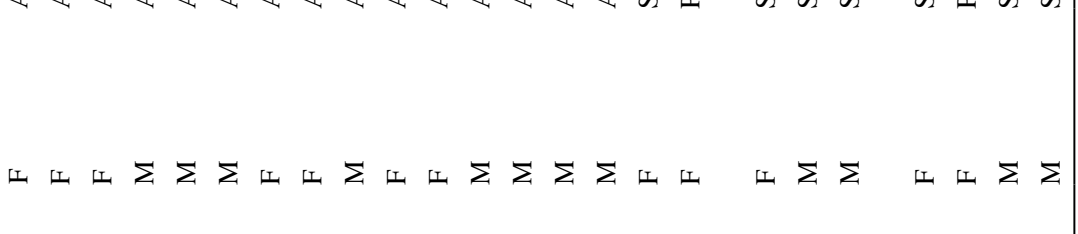

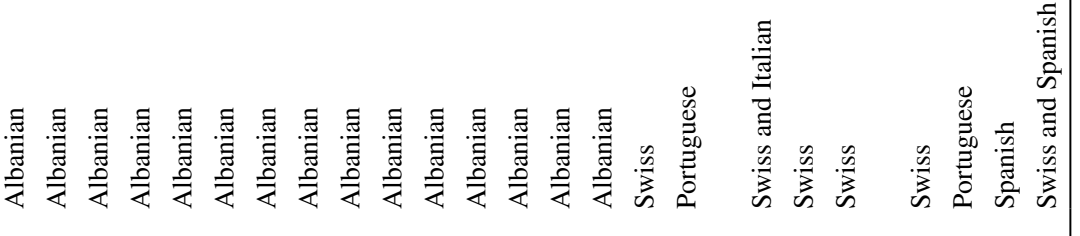

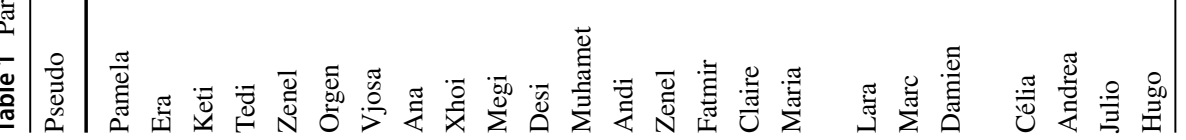




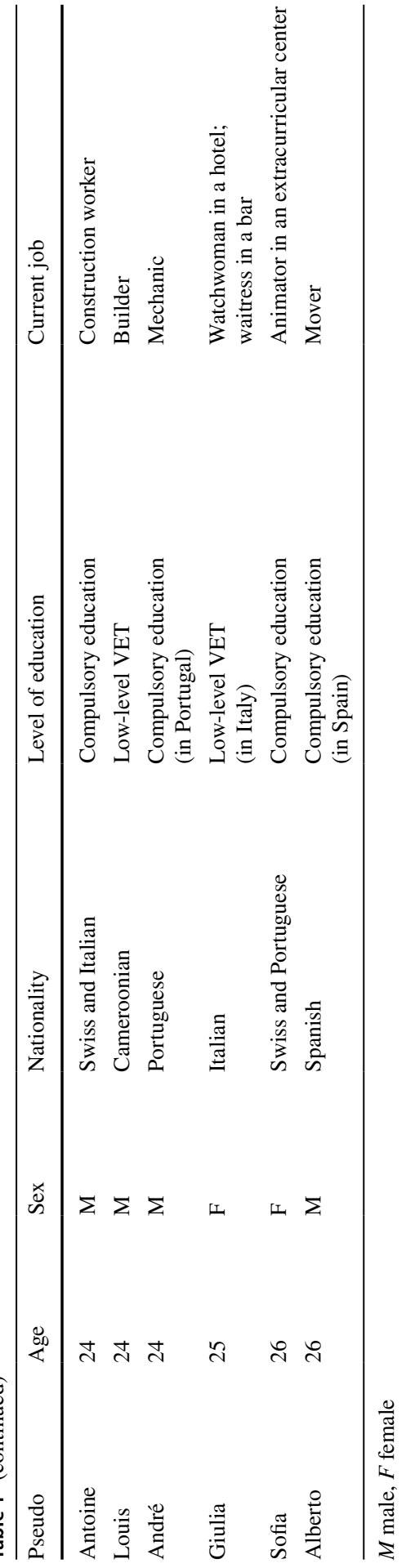


part covered participants' identity and future plans, with questions like "What kind of person would you like to become in the future?" (for more details, see Masdonati et al., 2020). Our study focused on the second part of the interview and, more specifically, on the answers given to the so-called lottery question-i.e., "If you win the lottery, would you keep working?" Based on their answer, they were asked the reasons why they would/would not continue working after hypothetically winning the lottery. Follow-up questions were asked to go deeper into their explanation.

\section{Analysis}

Analyses were carried out following the thematic analysis procedure (Braun \& Clarke, 2006). The research team was composed of six researchers: three researchers from an Albanian university; one professor and two PhD students from a Swiss university. The Swiss team first carried out the analysis on the Swiss data following Braun and Clarke's first five stages of thematic analysis: familiarizing with the data, generating initial codes, searching for themes, reviewing potential themes, and defining and naming theme in a codebook. The Albanian team then applied the resulting codebook to the Albanian data. Finally, the two sets of data were put together to compare results from both countries and produce the report, which corresponds to the sixth and final stage of thematic analysis. Analyses were also informed by the consensual qualitative research recommendations (CQR; Hill et al., 2005) in order to ensure that results reflect the research team members understanding. In line with $\mathrm{CQR}$, before and during the analysis procedure regular online team meetings were thus organized to coordinate and adjust the procedure.

\section{Results}

The presentation of the results is organized in three parts. First, we address the yes/ no answers to the lottery question, namely the proportion of people who would continue working even if they won the lottery, and the conditions under which they would possibly continue working. Second, we present their explanation of these answers, namely the reasons why they would continue working or not. Third, differences and similarities between the answers and explanations of Albanian and Swiss participants are addressed. Table 2 presents an overview of the categories and frequencies emerged from our analyses.

\section{Would you still work?}

Twenty percent of the total sample in both countries $(n=4)$ stated that they would stop working if winning the lottery, whereas the others would continue working. The participants who would stop working answered that they would have enough money to avoid the constraints of the working life, such as having to obey orders and rules or experiencing stressful situations. Pamela (20 y.o., Albania) told us: "No, I would enjoy my life and I would spend my money. I would go very often on vacation and 
Table 2 Categories covering the answers to the lottery question

\begin{tabular}{llll}
\hline Categories & Albania & Switzerland & Total \\
\hline Would you still work? & & & \\
No & 2 & 2 & 4 \\
Yes & 13 & 13 & 26 \\
$\quad$ Change contents & 13 & 9 & 22 \\
Gain autonomy & 13 & 5 & 18 \\
Change rhythms & 9 & 4 & 13 \\
Reasons for continuing working & & \\
Being busy & 12 & 11 & 23 \\
Feeding a passion & 8 & 4 & 12 \\
Feeling useful & 2 & 3 & 5 \\
Growing & 3 & 2 & 5 \\
\hline
\end{tabular}

go out for nightlife. Work is a stressful process for me, a physical and psychological burden." This was also the case of Alberto (26 y.o., Switzerland) whose plan would be to buy and rent houses so he would not have to obey and take orders from anyone.

The other 26 participants would continue working even if they won the lottery. However, they all reported that they would change their current situation, their answers to the lottery question being "yes, but..." Both in Albania and Switzerland, these changes covered three features: work contents, autonomy, and rhythms.

\section{Change contents}

Among participants who would continue working, around two-thirds would modify the contents of their job and focus exclusively on activities that they enjoy doing, or that are more prestigious and socially valued. Their financial situation being secured, they could prioritize their emotional and social satisfaction at work. To achieve that goal, some of them would also consider going back to school. For example, Keti (20 y.o., Albania) said: "If I win the lottery, I would start high school again to increase my average so that I can access university and study to become an Italian language teacher." In Switzerland, Sofia, who currently has two jobs, would continue to work in the one she likes and drop the other one.

\section{Gain autonomy}

Half of the sample would also like to have more autonomy at work, for example by becoming independent and having his/her own business. For them, more autonomy would lead to greater self-confidence, awareness of one's own value, skills and ideas beyond the opinions of others. This was the case for Orgen (21 y.o., Albania) who explained that he would opt for opening his own bar, and André (24, Switzerland), who would run his own mechanic's business. 


\section{Change rhythms}

Six participants indicated that they would change the work rhythms: They would work fewer hours in order to have more free time and fun, a better work-life balance, and less exhausting working days. For example, Tedi (20 y.o, Albania) stated: "If I won the lottery I would work four or six hours a day, not like now that I have to work more than $10 \mathrm{~h}$ a day". In the Swiss context, Louis (24 y.o) said, "For the balance of my life I could put myself at 50\% [working part-time] somewhere and do something I really like, continue to work, continue to take care of myself, for my well-being."

\section{Reasons for continuing working}

Participants who would continue working despite winning the lottery were asked to explain why they would do that. We identified four types of reasons for continuing to work: being busy, feeding a passion, feeling useful, and growing.

\section{Being busy}

The most frequent reason for continuing working was the importance for participants of being busy and avoiding idleness. Tedi (20 y.o., Albania) explained: "Yes, it's better working than being unemployed, [...] it's worthy. Work helps me to live better. Time passes quickly and happily. Work helps me to have emotional and physical balance." This was also the case of Claire (20 y.o., Switzerland): "Even if I had money, a job it's a routine [...] because staying at home all the time, personally, I couldn't."

\section{Feeding a passion}

For some participants, working is also an opportunity to live a vocation, do things that they consider important, meaningful, or simply enjoyable. For example, Fatmir (25 y.o., Albania) stated: "Of course, I would continue to work. I would continue to work to develop my desires and passions." In Switzerland, Célia (23 y.o) added: "My goal, even if I win the lottery, would be to continue to work with people, because I love what I do."

\section{Feeling useful}

Other young people would continue working because work enables them to feel useful and contribute to the general well-being of others, such as family members. Zenel (25 y.o., Albania), answered the following: "Even if I won the lottery I would still work. I cannot stay without working because I need to take care of my family." 
For her part, Lara (21 y.o., Switzerland) explained that she would set up a lowbudget real estate management, so that it could be accessible to everyone.

\section{Growing}

The last type of reason explaining why young people would continue working despite winning the lottery is the fact that work allows growth and personal development. In this sense, Era (20 y.o., Albania) considered that,

One cannot work just because of money: you have to work also for yourself and to grow through work, as well as to know other people. Working has a lot of benefits, you have the chance to learn a lot, to meet more trained people and learn from them.

In the Swiss sample, Julio (23 y.o.) explained that his goal was to become an educator; he explained: "You follow someone from A to Z. Your goal is, in inverted commas, to reintegrate him into social life. [...] It's a really good job."

\section{Work orientations in context}

Participants in Albania and Switzerland answered the lottery question in a similar way, albeit also covering some minor differences.

\section{Similarities between Albania and Switzerland}

Both in Albania and Switzerland, when asked what they would do if they won the lottery, most participants would continue working. Additionally, young people from the two contexts would yet change some aspects of their job, and converge concerning the aspiration to focus on more interesting and meaningful work contents. Also, young people in both countries aspired to have more autonomy and to somehow reduce the pace of their working lives. Finally, Albanian and Swiss participants converge concerning the reasons why they would continue working despite winning the lottery, given that we did not found any category of reasons that was specific to one country.

\section{Differences between Albania and Switzerland}

Beyond these general similarities between the two groups, we identified some possible differences when comparing frequencies and exploring more in depth the changes that participants would make in their job and the reasons why they would continue working. First, the aspiration to changes in their jobs were more popular among Albanian participants. Most of them would indeed become independent, work fewer hours, or focus on targeted job contents, which was less often the case for participants from Switzerland. Particularly, the search for more autonomy seems to specifically concern youth in Albania. Second, most Albanian youth who would change their working sector reported that they would do that for health issues, as the job they were doing was hard and source 
of health issues. Yet, health issues were only mentioned by one interviewee from the Swiss sample. Third, within the category "Change in Rhythms" we noticed that, after winning the lottery, many Albanian youth would opt for a period of rest, as their current job is exhausting. In contrast, youth from Switzerland would simply like to have fun for a few months before resuming working or studying. Fourth, among the five participants saying that they would continue working because they need to feel useful through work, only Albanian youth specifically mentioned family responsibilities, expectations, or obligations.

\section{Discussion}

This study focused on the work orientations of low-qualified young workers within two contrasted socioeconomic contexts: Albania and Switzerland. Results showed that most participants from both countries would continue to work even if they won the lottery, but under some conditions. These conditions were stronger for Albanian interviewees, possibly because they are in a more challenging labor market as compared to participants from Switzerland. In the following sections, we address the types of work orientations, current work importance, and contextual influences, as well as the study limits and future perspectives. Finally, we will share implications for career counseling.

\section{Towards five types of work orientations}

The reasons mentioned by participants to explain why they would continue working even if they won the lottery can be associated to the types of work orientations addressed in the literature (Willner et al., 2020; Wrzesniewski et al., 1997). What we named in our analyses Being busy corresponds then with the "busyness" work orientation; Feeding a passion is close to the "calling" orientation; Feeling useful matches the "social embeddedness" orientation; Growing has similarities with the "career" orientation; and participants who would stop working can be considered as "job"-oriented. Thus, our results tend to support the five-type model of work orientations suggested by Willner et al. (2020) and Lipshits-Braziler et al. (2020). Specifically, our findings confirm the salience of the busyness orientation to work, an orientation that was not addressed in the first job/career/calling typology by Wrzesniewski et al. (1997). Being busy was indeed the most frequently mentioned reason for continuing working, participants maintaining that work keeps them occupied and provides them with structure and rhythm in life. This result seems to corroborate that work in general is a major context for people and occupies a psychological space in their lives, regardless of its contents and the job characteristics (Blustein et al., 2017, 2019).

\section{Conditions for work commitment}

The fact that most participants would continue to work despite experiencing poor working conditions might support Highhouse et al. (2010) findings stressing that young people tend to answer more positively to the lottery question than older ones. 
However, our results also suggest the existence of a gap between young adults' representations of work in general and their concrete current job experiences (CohenScali et al., 2020). For most participants, work as a life sphere seems to have a considerable importance in their life, although their current job is hard and unsatisfying. This could explain why, if they won the lottery, they would continue working provided modifying many facets of their current job: they would redirect the contents of their job (i.e., focusing exclusively on socially valued, prestigious activities or the ones they enjoy doing), search for more autonomy (i.e., becoming independent and having their own business), and decelerate the rhythms of work (i.e., work fewer hours and have a better work-life balance). Thus, work in general and as a life sphere seems meaningful to them (Rosso et al., 2010), but not the job they are currently doing. Indirectly, these findings also provide insights on the characteristics of a meaningful work from young adults' perspective. These characteristics-i.e., interesting contents, autonomy, and decent work rhythms - are close to the key determinants of work commitment stressed by Wielers and Meer (2020), namely development opportunities, autonomy, and job security.

\section{Contextual influences on work orientations}

We identified four possible differences between the two compared countries. In contrast to participants from Switzerland, Albanian young workers would more frequently change some aspects of their jobs, seemed to encounter more health issues at their workplace, would opt for a period of rest as their job was exhausting, and mentioned that family obligations would encourage them to continue working. The two contrasted working contexts may account for these differences, rather than distinct work orientations. The more precarious Albanian labor market, involving more exhausting and insecure working conditions, might indeed explain why Albanian participants gave more "Yes, but..." answers to the lottery question. Moreover, these differences might reveal distinct cultural contexts regarding the responsibilities towards family, which are higher in more collectivist society such as Albania (Hofstede, 2020).

\section{Limits and future perspectives}

A first limitation of our study concerns the comparability of the two samples, given that the Albanian sample was composed both of rural and urban participants, whereas there was no distinction within the Swiss sample. The analysis strategy also implied some possible biases, given that the codebook was conceived by the Swiss research team and then submitted to Albanian team. This procedure might have steered the analyses of the Albanian data. Moreover, we acknowledge that, based on the lottery question, our study focused on young workers' representations of work and not on what they would actually do if they won the lottery. Additionally, purposive sampling reduces the transferability of the results, as some profiles of young adults may have been overlooked. Thus, similarities and differences between the two countries are hypothetical and should be interpreted carefully. We also lack precise information on participants' socioeconomic 
profile, as well as the type of working contracts. Future research could broaden the sample of both countries to include more diverse profiles of young adults and collect more precise information on their working situation. Moreover, research teams might independently produce their own codebooks and compare them to find consensus. A comparison of our results with data from other countries that differ from Albania and Switzerland according to cultural and labor market indicators is also recommended. Finally, qualitative longitudinal studies could provide insights on the potential evolution on young adults' work orientations.

\section{Implications for career counseling}

A first implications of our study is the importance of investigating counselees' work orientation during the counseling process, in order to take it into account when exploring future plans. The lottery question can also be used not only for research purposes, but also as an intervention input to investigate counselees' representations of work and what makes it meaningful for them specifically. More generally, considering the crucial role of the STWT for the construction of young people's meaning of working (Masdonati \& Fournier, 2015), interventions should promote decent and dignified work (i.e., involving fair pay, autonomy, and adequate workload) and help young people to stay active and critical when entering the labor market (Blustein et al., 2019; Kenny et al., 2019).

\section{Conclusion}

Most of low-qualified young workers participating in this study would continue working even if they won the lottery, but under certain conditions. The reasons why they would continue to work can be summarized in four main categories, namely being busy, feeding a passion, feeling useful, and growing. Both Albanians and Swiss young workers wanted more autonomy and slow down the pace of their working lives, with Albanian participants evoking more drastic changes and the need to take on family responsibilities. Overall, this study stresses the importance of taking into account the variety of people's possible work orientations when trying to understand young adults work experiences and subjective meaning of work. They also indicate that current work situations of low-qualified young adults often differ from what they actually expect from work, which might contribute to jeopardize their experience of the labor market integration and subsequent career paths.

Acknowledgements We acknowledge the valuable collaboration of Nadia Ferreira Coelho, Stéphanie Dinis Teixeira, and Robin Zufferey for data collection and analyses.

Funding Open Access funding provided by Université de Lausanne.

Open Access This article is licensed under a Creative Commons Attribution 4.0 International License, which permits use, sharing, adaptation, distribution and reproduction in any medium or format, as long as you give appropriate credit to the original author(s) and the source, provide a link to the Creative Commons licence, and indicate if changes were made. The images or other third party material in this article 
are included in the article's Creative Commons licence, unless indicated otherwise in a credit line to the material. If material is not included in the article's Creative Commons licence and your intended use is not permitted by statutory regulation or exceeds the permitted use, you will need to obtain permission directly from the copyright holder. To view a copy of this licence, visit http://creativecommons.org/licen ses/by/4.0/.

\section{References}

Arvey, R. D., Harpaz, I., \& Liao, H. (2004). Work centrality and post-award work behavior of lottery winners. The Journal of Psychology, 138, 404-420. https://doi.org/10.3200/JRLP.138.5.404-420

Masdonati, J., \& Fournier, G. (2015). Life design, young adults, and the school-to-work transition. In L. Nota \& J. Rossier (Eds.), Handbook of life design: From practice to theory and from theory to practice (pp. 117-133). Hogrefe Publishing

Masdonati, J., Fedrigo, L., \& Zufferey, R. (2020). Emerging job precariousness: Work experiences and expectations of low-qualified young workers in Switzerland. Emerging Adulthood. https://doi.org/ $10.1177 / 2167696820933730$

Masdonati, J., Massoudi, K., Blustein, D. L., \& Duffy, R. D. (2021). Moving toward decent work: Application of the psychology of working theory to the school-to-work transition. Journal of Career Development. https://doi.org/10.1177/0894845321991681

Blustein, D. L., Masdonati, J., \& Rossier, J. (2017). Psychology and the International Labor Organization: The role of psychology in the Decent Work Agenda. International Labor Organization (ILO). Retrieved from http://www.ilo.org/global/research/publications/WCMS_561013/lang--en/index.htm

Blustein, D. L., Kenny, M., Di Fabio, A., \& Guichard, J. (2019). Expanding the impact of the psychology of working: Engaging psychology in the struggle for decent work and human rights. Journal of Career Assessment, 27, 3-28. https://doi.org/10.1177/1069072718774002

Braun, V., \& Clarke, V. (2006). Using thematic analysis in psychology. Qualitative Research in Psychology, 3, 77-101. https://doi.org/10.1191/1478088706qp063oa

Cernaj, E. (2019). Unemployment in Albanian society as one of the difficult and persistent challenges faced by Albanian citizens, especially young people. Beder University Journal of Educational Sciences, 20(1), 46-57.

Cohen-Scali, V., Masdonati, J., Disquay-Perrot, S., Ribeiro, M. A., Vilhjálmsdóttir, G., Zein, R., KaplanBucciarelli, J., Moumoula, I., Aisenson, G., \& Rossier, J. (2020). Emerging adults' representations of work: A qualitative research in seven countries. Advance online publication. https://doi.org/10. $1177 / 2167696820963598$

Danziger, S., \& Ratner, D. (2010). Labor market outcomes and the transition to adulthood. The Future of Children, 20, 133-158. https://doi.org/10.1353/foc.0.0041

de Bruijn, B., Filipi, G., Nesturi, M., \& Galanxhi, E. (2015). Youth in Albania: Challenges in changing times. INSTAT.

Egdell, V., \& Beck, V. (2020). A capability approach to understand the scarring effects of unemployment and job insecurity: Developing the research Agenda. Advance online publication. https://doi.org/10. 1177/0950017020909042

Egger, M., Mattmann, M., \& Marti, M. (2020). Chômage de longue durée: quels sont les facteurs de risque? [Long-term unemployment: What are the risk factors?]. La Vie Economique, 3, 16-19.

Federal Statistical Office. (2018). 90.9\% des jeunes avec un titre du degré secondaire II jusqu'à l'âge de 25 ans $[90.9 \%$ of young people with a title from the secondary degree II until the age of 25 years old]. Neuchâtel, Switzerland: Federal Statistical Office. Retrieved from https://www.bfs.admin.ch/ bfs/fr/home/actualites/quoi-de-neuf.assetdetail.4282071.html

Federal Statistical Office. (2019). Indicateur de la législature: Taux de chômage des jeunes [Indicator for the legislature: Youth unemployment rate]. Neuchâtel, Switzerland: Federal Statistical Office. Retrieved from https://www.bfs.admin.ch/bfs/fr/home/statistiques/themes-transversaux/monitoringprogramme-legislature/tous-les-indicateurs/ligne-directrice-1-prosperite/taux-chomage-jeunes.html

Fouad, N. A., \& Bynner, J. (2008). Work transitions. American Psychologist, 63, 241-251. https://doi. org/10.1037/0003-066X.63.4.241

Fournier, G., Lachance, L., Viviers, S., Lahrizi, I. Z., Goyer, L., \& Masdonati, J. (2020). Development and initial validation of a multidimensional questionnaire on the relationship to work (RWQ). 
International Journal for Educational and Vocational Guidance, 20, 123-168. https://doi.org/10. 1007/s10775-019-09397-0

Harpaz, I., \& Fu, X. (2002). The structure of the meaning of work: A relative stability amidst change. Human Relations, 55, 639-667. https://doi.org/10.1177/0018726702556002

Highhouse, S., Zickar, M. J., \& Yankelevich, M. (2010). Would you work if you won the lottery? Tracking changes in the American work ethic. Journal of Applied Psychology, 95, 349-357. https://doi. org/10.1037/a0018359

Hofstede, G. (2020). What about Albania? Retrieved from https://www.hofstede-insights.com/countrycomparison/albania,switzerland/

Hoxhaj, M. (2017). Youth unemployment in Albania, causes and consequences. Euro Economica, 36(2), $159-168$.

Kamberi, G., \& Çela, A. (2019). Youth study Albania 2018/2019. Friedrich Ebert-Stiftung

Kazimna, P., Holu, Y. A., Alfa, A., Tchonda, M., Pari, P., \& Masdonati, J. (2020). What work should be and bring: Representations of decent work in Togo. African Journal of Career Development, 12, 397-414. https://doi.org/10.1080/14780887.2015.1021941

Kenny, M. E., Blustein, D. L., Liang, B., Klein, T., \& Etchie, Q. (2019). Applying the Psychology of Working Theory for transformative career education. Journal of Career Development. https://doi. org/10.1177/0894845319827655

Krahn, H. J., Howard, A. L., \& Galambos, N. L. (2015). Exploring or floundering? The meaning of employment and educational fluctuations in emerging adulthood. Youth \& Society, 47, 245-266. https://doi.org/10.1177/0044118X12459061

Lipshits-Braziler, Y., Abessolo, M., Santilli, S. \& Di Maggio, I. (2020). Work orientation questionnaire: Measurement invariance and criterion validity among Swiss, Israeli, and Italian workers. International Journal for Educational and Vocational Guidance. https://doi.org/10.1007/ s10775-020-09436-1

Mattmann, M., Walther, U., Frank, J., \& Marti, M. (2017). L'évolution des emplois atypiques précaires en Suisse [Evolution of atypical precarious jobs in Switzerland]. Ecoplan. Retrieved from https://www. newsd.admin.ch/newsd/message/attachments/50256.pdf

Meyer, T. (2018). De l'école à l'âge adulte: parcours de formation et d'emploi en Suisse [From school to adulthood: Education and employment paths in Switzerland]. Social Change in Switzerland, 13. https://doi.org/10.22019/SC-2018-00001

Nathani, C., Hellmüller, P., Rieser, C., Hoff, O., \& Nesarajah, S. (2017). Ursachen und Auswirkungen des Strukturwandels im Schweizer Arbeitsmarkt [Causes and effects of structural changes in the Swiss labor market]. Bern, Switzerland: State Secretariat for Economic Affairs.

OECD. (2017a). OECD employment outlook 2017. OECD. https://doi.org/10.1787/empl_outlo ok-2017-en

OECD. (2017b). Transition from school to work: How hard is it across different age groups? Education Indicators in Focus, 54. OECD Publishing. https://doi.org/10.1787/1e604198-en

Rosso, B. D., Dekas, K. H., \& Wrzesniewski, A. (2010). On the meaning of work: A theoretical integration and review. Research in Organizational Behavior, 30, 91-127. https://doi.org/10.1016/j.riob. 2010.09.001

Schoon, I., \& Bynner, J. (2019). Young people and the Great Recession: Variations in the school-towork transition in Europe and the United States. Longitudinal and Life Course Studies, 10, 153-173. https://doi.org/10.1332/175795919X15514456677349

Schoon, I., \& Heckhausen, J. (2019). Conceptualizing individual agency in the transition from school to work: A social-ecological developmental perspective. Adolescent Research Review, 4, 135-148. https://doi.org/10.1007/s40894-019-00111-3

Schoon, I., \& Lyons-Amos, M. (2016). Diverse pathways in becoming an adult: The role of structure, agency and context. Research in Social Stratification and Mobility, 46, 11-20. https://doi.org/10. 1016/j.rssm.2016.02.008

Secrétariat d'état à l'économie. (2017). Chômage des jeunes [Youth unemployment]. Bern: State Secretariat for Economic Affairs. Retrieved from https://www.seco.admin.ch/seco/fr/home/Arbeit/Arbei tslosenversicherung/arbeitslosigkeit/Jugendarbeitslosigkeit.html

Sharabi, M., \& Harpaz, I. (2019). To work or not to work: Variables affecting non-financial employment commitment over time. International Labour Review, 158(2), 393-417.

Snir, R., \& Harpaz, I. (2009). Cross-cultural differences concerning heavy work investment. Cross-Cultural Research, 43, 309-319. https://doi.org/10.1177/1069397109336988 
Tomlinson, J., Baird, M., Berg, P., \& Cooper, R. (2018). Flexible careers across the life course: Advancing theory, research and practice. Human Relations, 71, 4-22. https://doi.org/10.1177/0018726717 733313

Vuolo, M., Mortimer, J. T., \& Staff, J. (2014). Adolescent precursors of pathways from school to work. Journal of Research on Adolescence, 24, 145-162. https://doi.org/10.1111/jora.12038

Wielers, R., \& van der Meer, P. H. (2020). Beyond income: Why we want to keep on working even if we don't need the money. Applied Research in Quality of Life. https://doi.org/10.1007/ s11482-020-09834-1

Willner, T., Lipshits-Braziler, Y., \& Gati, I. (2020). Construction and initial validation of the Work Orientation Questionnaire. Journal of Career Assessment, 28, 109-127. https://doi.org/10.1177/10690 72719830293

Wrzesniewski, A., McCauley, C., Rozin, P., \& Schwartz, B. (1997). Jobs, careers, and callings: People's relations to their work. Journal of Research in Personality, 31, 21-33. https://doi.org/10.1006/jrpe. 1997.2162

Yeung, W.-J.J., \& Yang, Y. (2020). Labor market uncertainties for youth and young adults: An international perspective. The ANNALS of the American Academy of Political and Social Science, 688, 7-19. https://doi.org/10.1177/0002716220913487

Publisher's Note Springer Nature remains neutral with regard to jurisdictional claims in published maps and institutional affiliations. 